\title{
Habitat use and gas bubble disease in southern cavefish (Typhlichthys subterraneus) *
}

\author{
Alex L.S. Schubert ${ }^{* *}$, Carl D. Nielsen ${ }^{* *}$, and Douglas B. Noltie ***
}

\section{SUMMARY}

In situ observations of habitat use by southern cavefish (Typhlichthys subterraneus) in a Missouri, U.S.A. spring suggest that groundwater discharge and that zones of substrate which have large interstitial spaces that fish can enter may be important components of the species' habitat. Such substrates may also facilitate smallscale dispersal. In addition, we document the first recorded case of gas bubble disease in a laboratory-held speciem of this species. Cavefish may be particularly susceptible to this malady, and the conditions under which it occurred are important to avoid should captive maintenance or propagation of this or related species be attempted.

\section{INTRODUCTION}

The southern cavefish (Amblyopsidae: Typhlichthys subterraneus) is a small, troglobitic species which occurs in karstic areas of central North America (Woods \& Inger, 1957). Its subterranean existence has made investigation of its ecology challenging. The resulting lack of information about the species constrains efforts to protect it, Missouri populations having been designated as "watchlisted" (Missouri Department of Conservation, 1991). In collecting specimens for a research project (Schubert, 1993), we made observations of in situ habitat use which, because of their relative scarcity in the recent literature, we document herein. The subsequent maintenance-related difficulties which arose are reported because of their relevance to researchers wishing to study captive individuals of this and related species.

* Contribution from the Missouri Agricultural Experiment Station, Project c-2 - 51001 - 4700, Journal Series No. 12, 101.

** Student.

*** Professor and author to whom correspondence should be directed. Fisheries and Wildlife Program, The School of Natural Resources, 112, Stephens Hall, University of Missouri - Columbia, Columbia - Missouri, U.S.A. 65211. 


\section{MATERIAL, METHODS AND RESULTS}

\section{Habitat use}

Capture Site: A single field collection was made via dip net on 11 April 1991 from a boxed spring (Spring No. 1) on the property of Ozark Fisheries, Inc. of Camden County, near Camdenton in central Missouri (SW 1/4, NE 1/4, SW 1/4, Sect. 25, T37N, R15W). Individuals had not been seen here previously, but an adjacent spring (Spring No. 2) ca. $150 \mathrm{~m}$ north has continuously yielded sightings of southern cavefish for decades (Smith, 1980; D.E. Figg, Endangered Species Coordinator, Missouri Department of Conservation, pers. comm.). There is no evidence to suggest that fish from Spring No. 1 constitute other than a naturally-occurring population. Only three specimens were removed from the site, leaving others behind. The sizes of two of the collected individuals were $0.98 \mathrm{~g} / 47 \mathrm{~mm}$ Total Length and $3.2 \mathrm{~g} / 66 \mathrm{~mm}$ TL, respectively. The third fish was similar in size to the larger of the other two, but was not measured directly because after collection it contracted a severe fungal infection (identified as Saprolegnia) and was submitted immediately post-mortem (20 April 1991) for necropsy/histopathology.

Spring No. 1 is fed diffusely (Fig. 1), with palpable groundwater discharging into the spring from at least five distinct substrate areas of clean, loosely-aggregated chert gravel (3-5 cm diameter) having large interstitial spaces. In contrast, non-discharge areas were overlain by a heavy layer of readily-suspended silt. The spring outflow was estimated at $0.35 \mathrm{~m}^{3} / \mathrm{s}$ and measured $14.4^{\circ} \mathrm{C}$ during the collection. The spring's volume was estimated at $45 \mathrm{~m}^{3}$. The water chemistry of adjacent springs that presumably share this aquifer has been characterized by Smith (1980).

Observations: SCUBA gear was used during the three hours time spent submerged in Spring No. 1. Silt suspension allowed only 30 minutes of completely unobstructed observation, however. During the time below, 8 separate individuals spanning a size range of 40 to $65 \mathrm{~mm}$ estimated TL were censused. Within the water column, undisturbed individuals occupied positions close to the bottom (within $0.5 \mathrm{~cm}$ ) at depths of 1.2 to $2.0 \mathrm{~m}$ below the water surface (1.7 to $2.5 \mathrm{~m}$ below grade). Individuals forayed higher into the water 
A.

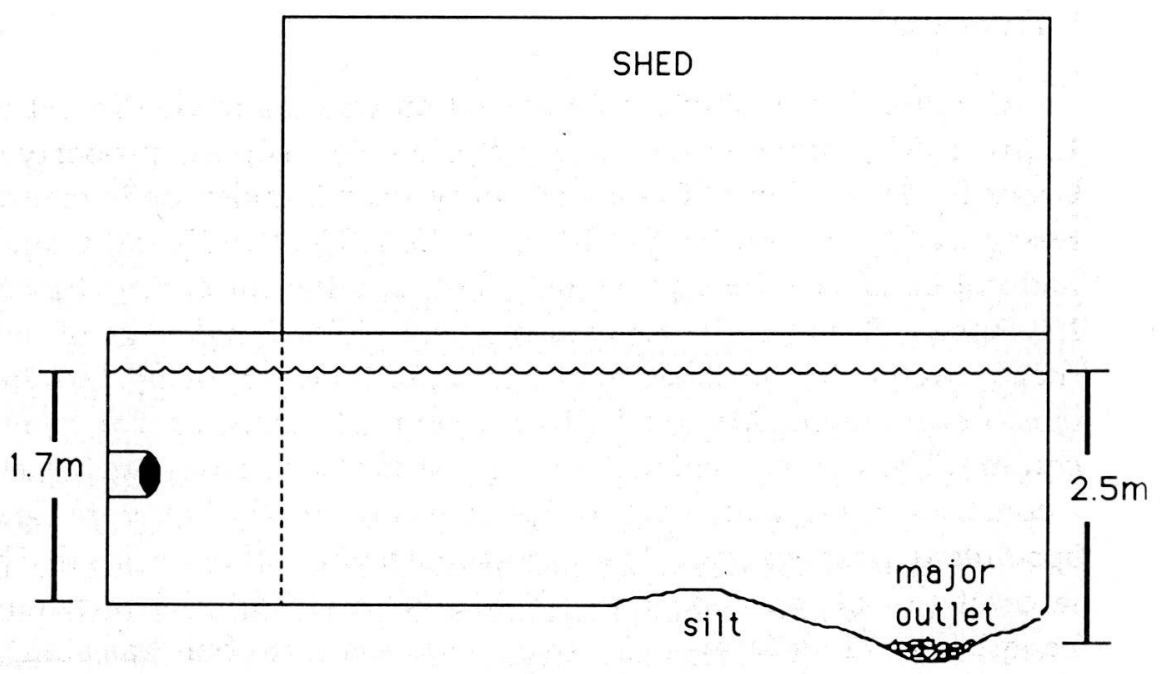

B.

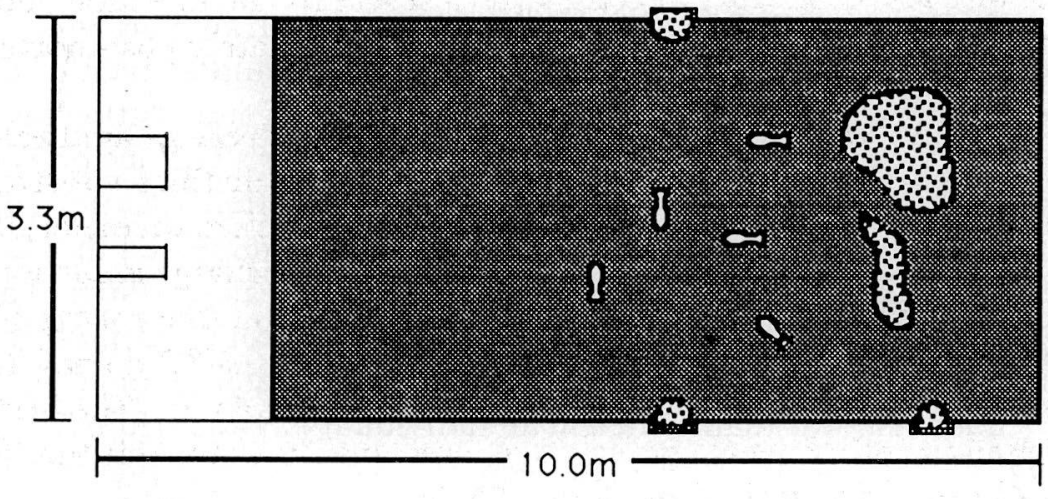

Gravel

Silt

Fish $\quad \Rightarrow$

Fig. 1 - Schematic diagram of side view (A) and top view (B) of Spring No. 1. Placement and orientation of cavefish is as seen at the initial opening of the spring access door. 
column only when over silt substrate areas and when being followed by the observer.

With respect to the substrate, undisturbed individuals seldom strayed from the positions they held atop the mound of substrate immediately «downstream» from the central zone of groundwater discharge (Fig. 1). Our capture attempts prompted these individuals to orient to and move towards the various groundwater discharge areas, and to disappear into the substrate therein, subsequently entering and exiting the gravel interstices periodically. Fish movements between substrate patches involved exiting the substrate and traversing the interjacent silted areas (Fig. 1). Neither prey capture attempts by the fish nor prey organisms were observed over either the gravel or silt substrate areas.

\section{Gas bubble disease}

Laboratory Holding Conditions: The three field-caught individuals were relocated immediately to a holding facility at the U.S. Fish and Wildlife Service's National Fisheries Contaminant Research Center (NFCRC) in Columbia, Missouri. Transport was accomplished by placing the specimens in a $90 \mathrm{l}$ insulated picnic cooler half-filled with ca. $45 \mathrm{l}$ of Spring No. 1 water. A snug-fitting layer of $3 \mathrm{~cm}$ thick styrofoam insulation set at the water's surface prevented sloshing (see Bechler, 1983). Additional aeration was not supplied. All three specimens were briefly $(1 / 2 \mathrm{hr})$ immersed in a 200 ppm formalin bath on arrival as a prophylactic measure (Piper et al., 1982:275). To this time, none of the specimens exhibited problems maintaining equilibrium or position within the water column.

Each fish was maintained in an individual $77 \mathrm{l}$ aquarium $(79 \mathrm{~cm}$ long $\times 32 \mathrm{~cm}$ wide $\times 30.5 \mathrm{~cm}$ deep) filled to $20 \mathrm{~cm}$ depth and $2 / 3$ submerged in a darkened large-volume water table. Part-volumes $(1.5 \mathrm{l})$ of the aquarium water were automatically replaced each quarter hour from a pressurized pipe. Water bath temperatures were maintained at $15^{\circ} \mathrm{C}$ by a cooling unit. The source for the aquarium replacement water was a $202 \mathrm{~m}$ deep on-site well, the flow from which is pumped atop a $12 \mathrm{~m}$ tower for aeration through a series of baffles and for subsequent distribution. The chemistry of the water has been well characterized (Hunn \& Greer, 1991) and closely resembled that of the fish's spring water (Smith, 1980). During the first two weeks of holding, none of the specimens exhibited problems 
maintaining equilibrium or water column position. All three successfully made the transition to cultured, live food (Amphipoda: Hyallela azteca) provided in abundance.

Disease Occurrence: On the morning of the 16th day of holding (26 April 1991), we decided to enhance water circulation in the two remaining fish's aquaria by introducing a single air-stone delivering compressed atmospheric air. On checking the animals about $12 \mathrm{~h}$ later, the larger of the two was found floating upright at the surface, its dorsal surface protruding when at rest. This fish was bloated and its attempts at submergence were ineffective: depths of only ca. $2 \mathrm{~cm}$ were reached, but just for brief periods and after much effort and vigorous but erratic swimming. Its bulging swim bladder, visible through the body wall, suggested overinflation. The aeration of both aquaria was halted immediately. Eight hours later, the affected individual had partially recovered. After 16 more hours, it had reassumed the appearance and behavior it displayed preceding this occurrence. The individual remains alive to this day.

The well water supplying the fish's aquaria routinely carries dissolved nitrogen at levels between 100 and $105 \%$ saturation at $18^{\circ} \mathrm{C}$, occasionally rising to $110-115 \%$ when water temperatures are increased to $25^{\circ} \mathrm{C}$ (I.E. Greer, NFCRC, pers. comm.). Greer also reports that dissolved oxygen levels averaged $8.0 \mathrm{mg} / \mathrm{l}$ over the period $1982-1987$, an $82 \%$ saturation level at $15^{\circ} \mathrm{C}$ determined using methods described in Colt (1984: 37) and APHA (1989: 4-155) and correcting for the NFCRC's benchmarked altitude ( $252 \mathrm{~m}$ above sea level). On repeating the events described above (sans fish) on 29 May 1991, similar levels of supplementary aeration raised measured dissolved oxygen concentrations from 8.2 to $9.3 \mathrm{mg} / \mathrm{l}$ at $15^{\circ} \mathrm{C}$ water temperature and that day's 980 mbar median air pressure (climatological data and conversions provided by NOAA/NWS Columbia Airport station; station altitude $273 \mathrm{~m}$ above sea level). This change represented an increase in oxygen saturation from $84 \%$ to $95 \%$. Other gases were not measured. When gas measuring equipment became available ( 21 January 1993), the dissolved gas saturation of the influent water measured $106.2 \%$ nitrogen, $83.1 \%$ oxygen, and $101.3 \%$ total gas pressure (Weiss saturometer, Eco-Enterprises, Model ES-3; Yellow Springs Instruments, Model 54ARC). 


\section{DISCUSSION}

\section{Habitat use}

Our observations that undisturbed southern cavefish seldom strayed far from zones of substrate that both hava large interstitial spaces and that discharge groundwater indicates that such features may be important elements of appropriate southern cavefish habitat. That disturbed individuals sought these areas directly suggests that shelter is one benefit they might provide. A variety of authors, including Eigenmann (1909: 72,73) and Bechler (1980), record Typhlichthys sheltering below rocks, and Bechler (pers. comm. in Brown \& Willis, 1984) makes mention of their ability to burrow in interstitial spaces.

The fish's orientation and movement directly towards the groundwater discharge zones indicates that the southern cavefish in this population may be positively rheotactic, as was observed by Poulson (1960, 1963), Bechler (per. comm. in Brown \& Willis, 1984), and has seen in related cavefish species (Layne \& Thompson, 1952; Poulson, 1963; Weise, 1957). This response may serve to guide individuals towards the shelter of the vesicular substrates commonly associated with discharge areas. Likewise, the occupation of positions low in the water column, also observed in Typhlichthys by Eigenmann (1909: 80), Poulson (1963), and Armstrong \& Williams (1971), may aid in maintaining their proximity to substrate shelter.

Because we observed neither prey nor prey capture attempts, we could not ascertain whether a relationship between habitat use and prey availability existed. However, vesicular substrates may harbor more, more accessible, or choicer food organisms, the fish's rheotactic responses maintaining their spatial association with such productive foraging areas. Foraging at the substrate has been observed in Typhlichthys by Poulson (1960). Foraging by the related cavefish Amblyopsis rosae also occurs at and within the substrate (Poulson 1960), and time spent foraging by A. spelaea within the substrate is related to forage availability (Mohr \& Poulson, 1966).

It is interesting that southern cavefish had not been previously reported from Spring No. 1, despite its long history of use. Given the proximity of the historical population in nearby Spring No 2, the invasion of Spring No. 1 via subterranean dispersal seems a likely scenario (see Poulson, 1960; Woods \& Inger, 1957). Movements of a simi- 
lar distance have been recorded for normally epigean species (Nelson \& Paetz, 1974) under similar circumstances.

The observation of only post-juvenile-sized individuals in Spring No. 1 suggests (1) that they represent older individuals that have exited a larger population more extensively distributed below ground, (2) that outflows had removed young from the system, (3) that the young present were simply hiding or too small to be noticed, or (4) that young previously produced there had been prompted to move elsewhere. Adults in Typhlichthys populations do tend to dominate the population structure (Poulson, 1963). Furthermore, one would anticipate a population of emigrants from a larger population to be composed mainly of adults (Poulson, 1960, 1963). Nonetheless, young should have been observable had they been present given the time of year the sampling occurred (Poulson, 1963). The reason for their absence remains uncertain, and further monitoring of the structure and dynamics of this population seems warranted.

\section{Gas bubble disease}

Diagnosis and Causation: As in many cases of suspected gas bubble disease, we were alerted to the problem post facto by the symptoms the stricken individual exhibited (Bouck et al., 1980; Marking, 1987). Our decision to ultimately endorse this diagnosis is based on the following.

First, the onset and termination of symptoms occurred with the addition and then withdrawal of supplementary aeration, respectively. While the rarity of these organisms prevented us from attempting to repeat the occurrence, gas bubble disease has been induced in a similar fashion in tank-held channel catfish (Ictalurus punctatus) (Bowser et al., 1983; Jones \& Lewis, 1976). Recovery on immersion in equilibrated water has likewise been recorded (Crunkilton et al., 1980; Dawley et al., 1976; Schiewe, 1974).

Second, the dissolved nitrogen levels which characterize NFCRC well water are frequently in excess of saturation levels, a necessary and often sufficient condition for the development of gas bubble disease. Interestingly, the symptoms in the affected fish arose during a period of rapidly declining atmospheric pressure when saturation conditions may have been exacerbated. With the passage of a storm front, barometric pressures dipped to 968 mbars during the occurrence (26/27 April 1991), the lowest level they had 
attained since the fish's capture (NOAA/NWS Columbia Airport station pressure). Alderdice \& Jensen (1985) have suggested that changing weather conditions may influence the onset of gas bubble disease symptoms.

Third, although the levels of supersaturation involved were probably not excessive, the occurrences of gas bubble disease at relatively low supersaturation levels is known (Bouck, 1980; Colt, 1986; Cornacchia \& Colt, 1984; Harvey \& Cooper, 1962; Jensen et al., 1985; Shrimpton et al., 1990b; Weitkamp \& Katz, 1980). Nitrogen is typically the offending gas in situations involving the extraction of water from deep well sources (Harvey, 1975; Matsue et al., 1953; Satomi, 1955; Weitkamp \& Katz, 1980). The aeration tower at the NFCRC does reduce the water's nitrogen content. However, in similar aeration towers, aeration commonly increases oxygenation levels and the nitrogen excess is not totally reduced (D'Aoust, 1989; Machado et al., 1987), potentially aggravating any incipient supersaturation problem. In addition, the positive buoyancy that affected fish exhibit forces them to respire the supersaturated water at the air-water interface (Johnson \& Katavic, 1984; Kramer \& Mehegan, 1981), which may complicate matters further (Alderdice \& Jensen, 1985; Johnson \& Katavic, 1984; Weitkamp \& Katz, 1980).

Finally, symptoms consistent with those we observed (swim bladder hyperinflation, excessive buoyancy, difficulties swimming) have been reported for a number of other fishes where supersaturation of the medium occurred and a diagnosis of gas bubble disease was made (Alderdice \& Jensen, 1985; Chamberlain et al., 1980; Cornacchia \& Colt, 1984; Crunkilton et al., 1980; Dannevig \& Dannevig, 1950; Egusa, 1959; Hauck, 1986; Henly, 1952; Jensen, 1988; Nash et al., 1977; Renfro, 1963; Rukavina \& Varenika, 1956; Shrimpton et al., 1990 a,b; Stround et al., 1975). These symptoms are consistent with Fidler's (1984) «Type 1» or Alderdice \& Jensen's (1985) «chronic» from of gas bubble disease/trauma (note: most of the literature cited herein does not distinguish between the potential forms).

Alternative Diagnoses: Another possible diagnosis fitting some of the observed symptoms is «swimbladder stress syndrome», attributable to a stress-induced malfunction of the swimbladder (Bagarinao \& Kungvankij, 1986; Clary \& Clary, 1978; Johnson \& Katavic, 1984; Kolbeinshavn \& Wallace, 1985). Elevated stress levels might 
have resulted from treating the affected fish for a Saprolegnia infection during the three days preceding this occurrence, the treatment involving immersion for 20 minutes in a separate $3 \mathrm{ppm}$ potassium permanganate solution each day. Given the fish's rapid recovery on the cessation of aeration, and the elevated nitrogen saturation levels typifying the NFCRC water source, a stress-related diagnosis seems less appropriate.

We also discount the suggestion that the affected fish was exhibiting decompression-related effects, some of which resemble the symptoms of gas bubble disease (Bishai, 1961; Feathers \& Knable, 1983; Tsvetkov et al., 1972). Such a diagnosis would not be consistent with the fish's collection from a shallow spring, or with the development of symptoms more than two weeks thereafter, since the effects of decompression typically manifest themselves more rapidly. We are familiar with the symptoms of decompression in southern cavefish, these having been observed in two specimens brought by divers to the surface from depths of 13 and $18 \mathrm{~m}$ respectively during a 30 June 1991 collection at another Missouri site. These effects were consistent with the descriptions of decompression-related difficulties encountered by other species (Bishai, 1961; Feathers \& Knable, 1983; Hauck, 1986; Tsvetkov et al., 1972). One of these cavefish did not survive the trauma and succembed on 4 July 1991. The other individual recovered, however, and remains alive to the present.

Implications: No previous report of cavefish exhibiting gas bubble disease could be found in the literature, despite others having maintained wild-caught individuals in captivity (Poulson, 1960, 1963), some using aerated well water (e.g. Bechler, 1983). Cavefish may be particularly susceptible to this problem, given that selection for tolerance of fluctuating saturation levels should be weak in the relatively constant conditions that typify groundwater and/or cave system (Brown \& Willis, 1984). The relatively shallow water depths these fish occur at in nature probably reduce the $\triangle$ Puncomp (Colt, 1986) these fish experience to levels less than zero, suggesting that their exposure to supersaturated conditions would be rare in any event.

In addition, T. subterraneus possesses a large swim bladder (Putnam, 1875) and is a physoclistous species (Regan, 1929), the adults lacking a pneumatic duct joining the swim bladder and the gastro-intestinal tract which would help vent gas accumulations 
(Chamberlain et al., 1980; Harvey, 1975; Shrimpton et al., 1990 a,b). This may also render them more susceptible to the effects of decompression (Bishai, 1961). In the related spring cavefish (Chologaster agassizi), individuals exhibited preferences for oxygenation levels in excess of a particular threshold, but did not discriminate between levels above that threshold (Hill, 1966, 1968). A similar lack of discrimination may prevent Typhlichthys from avoiding supersaturated conditions when they arise. Finally, that it was the larger cavefish specimen that developed gas bubble disease is consistent with other findings regarding the susceptibility of larger individuals within other species (Alderdice \& Jensen, 1985; Dawley et al., 1976; Marsh \& Gorham, 1905; Meekin \& Allen, 1974; Rucker, 1975; Shirahata, 1966). Because the southern cavefish is a species at risk, and thus a candidate for captive maintenance and/or artificial propagation, future culture personnel need to be aware of this susceptibility to gas bubble disease.

\section{ACKNOWLEDGEMENTS}

D.E. Figg, L.D. Burger and J.E. Rathert assisted with the Spring No. 1 collection, made under Missouri Department of Conservation Collector's Permit 2820. K. Lewis of Ozark Fisheries, Inc. granted us access to the spring. Dr. E. Little provided the NFCRC holding facilities, P.E. Guinan some of the climatic data, and R. King and I.E. Greer the NFCRC water supply and chemistry data. I.E. Greer also performed the NFCRC saturation analyses. We greatly appreciated the efforts of I.E. Greer and Drs. T.L. Poulson, G.R. Bouck and especially J. Colt in reviewing drafts of the manuscript. Funding for this work was provided by grants from the Missouri Department of Conservation and the Missouri Agriculture Experiment Station to the senior author (DBN) This is a contribution from the Missouri Cooperative Fish and Wildlife Research Unit (cooperating organizations: U. S. National Biological Survey; Missouri Department of Conservation; The School of Natural Resources, University of Missouri - Columbia, Wildlife Management Institute).

\section{REFERENCES}

ALDERDICE, D.F., and J.O.T. JENSEN. 1985. Assessment of the influence of gas supersaturation on salmonids in the Nechako River in relation to Kemano completion. Can. Tech. Rep. Fish. Aquat. Sci. 1386:viii + 48 pp.

AMERICAN PUBLIC HEALTH ASSOCIATION. 1989. Standard Methods for the Examination of Water and Wastewater, 17th edition. American Public Health Association, Washington, D.C.

ARMSTRONG, J.G., and J.D. WILLIAMS. 1971. Cave and spring fishes of the southern bend of the Tennessee River. J. Tenn. Acad. Sci. 46:107-115.

BAGARINAO, T., and P. KUNGVANKIJ. 1986. An incidence of swimbladder stress syndrome in hatchery-reared sea bass (Lates calcarifer) larvae. Aquacult. 51:181-188.

BECHLER, D.L. 1980. The evolution of agonistic behavior in amblyopsid fishes. Ph. D. thesis, Saint Louis University, St. Louis, Missouri, U.S.A. xi +160 pp.

BECHLER, D.L. 1983. The evolution of agonistic behavior in amblyopsid fishes. Behav. Ecol. Sociobiol. 12:35-42. 
BISHAI, H.M. 1961. The effect of pressure on the distribution of some Nile fish. J. Exp. Zool. 147:113-124.

BOUCK, G.R. 1980. Etiology of gas bubble disease. Trans. Am. Fish. Soc. 109:703-707.

BOUCK, G.R., B. D'AOUST, W.J. EBEL and R. RULIFSON. 1980. Atmospheric gas supersaturation: educational and research needs. Trans. Am. Fish. Soc. 109:769-771.

BOWSER, P.R., R. TOAL, H.R. ROBINETTE and M.W. BRUNSON. 1983. Coelomic distention in channel catfish fingerlings. Progr. Fish-Cult. 45:208-209.

BROWN, A.V., and L.D. WILLIS. 1984. Cavefish (Amblyopsis rosae) in Arkansas: populations, incidence, habitat requirements and mortality factors. Final Report, Arkansas Game and Fish Commission, Federal Aid Project E-1-6. ii + 61 pp.

CHAMBERLAIN, G.W., W.H. NEILL, P.A. ROMANOWSKY and K. STRAWN. 1980. Vertical responses of Atlantic croaker to gas supersaturation and temperature change. Trans. Am. Fish. Soc. 109: 737-750.

CLARY, J.R., and S.D. CLARY. 1978. Swim bladder stress syndrome. Salmonid [March/April]: 8-9.

COLT, J. 1984. Computation of Dissolved Gas Concentrations in Water as Functions of Temperature, Salinity, and Pressure. American Fisheries Society Special Publication 14:vi-154.

COLT, J. 1986. Gas supersaturation - impact on the design and operation of aquatic systems. Aquacult. Eng. 5:49-85.

CORNACCHIA, J.W., and J.E. COLT. 1984. The effects of dissolved gas supersaturation on larval striped bass, Morone saxatilis (Walbaum). J. Fish Dis. 7:15-27.

CRUNKILTON, R.L., J.M. CZARNEZKI and L. TRIAL. 1980. Severe gas bubble disease in a warmwater fishery in the midwestern United States. Trans. Am. Fish. Soc. 109:725-733.

D'AOUST, B.G. 1989. Gas bubble disease - an appraisal. Fish Farmer, May/June:34-36.

DANNEVIG, A., and G. DANNEVIG. 1950. Factors affecting the survival of fish larvae. J. Cons. Int. l'Explor. Mer 15:277-283.

DAWLEY, E.M., M. SCHIEWE and B. MONK. 1976. Effects of long-term exposure to supersaturation of dissolved atmospheric gases on juvenile chinook salmon and steelhead trout in deep and shallow tank tests, p. 1-10. In D.H. Fickeisen and M.J. Schneider (eds.). Gas Bubble Disease. Conf-741033, Technical Information Center, Energy Research and Development Administration, Oak Ridge, Tennessee, USA.

EIGENMANN, C.H. 1909. Cave Vertebrates of America - A Study in Degenerative Evolution. Carnegie Institution of Washington, Pub. No. 104. $x+241$ pp.

EGUSA, S. 1959. The gas disease of fish due to excess of nitrogen. J. Fac. Fish. Anim. Husbandry Hiroshima Univ. 2:157-185.

FEATHERS, M.G., and A.E. KNABLE. 1983. Effects of depressurization upon largemouth bass. N. Amer. J. Fish. Manage. 3:86-90.

FIDLER, L.E. 1984. A study of biophysical phernomena associated with gas bubble trauma in fishes. Report to the Department of Fisheries and Oceans, Vancouver, British Columbia, by Penny Applied Sciences, Ltd., Penny, British Columbia, Canada. 132 pp.

HARVEY, H.H. 1975. Gas disease in fishes - a review, p. 450-485. In W.A. Adams (ed.). Chemistry and Physics of Aqueous Gas Solutions. The Electrochemical Society, Inc., Princeton, New Jersey. xii +521 pp.

HARVEY, H.H., and A.C. COOPER. 1962. Origin and treatment of a supersaturated river water. Int. Pac. Salmon Fish. Comm. Prog. Rep. 9:iii +19 pp.

HAUCK, A.K. 1986. Gas bubble disease due to helicopter transport of young pink salmon. Trans. Amer. Fish. Soc. 115:630-635.

HENLY, E. 1952. The influence of the gas content of sea water on fish and fish larvae. Rapp. Proces-verb. Reunions, Cons. Int. l'Explor. Mer 131:24-27.

HILL, L.G. 1966. Studies on the biology of the spring cavefish, Chologaster agassizi Putman. Ph.D. thesis, University of Louisville, Louisville, Kentucky. iv +105 pp.

HILL, L.G. 1968. Oxygen preference in the spring cavefish, Chologaster agassizi. Trans. Amer. Fish. Soc. 97:448-454. 
HUNN, J.B., and I.E. GREER. 1991. Influence of sampling on blood chemistry of Atlantic salmon. Prog. Fish-Cult. 53:184-187.

JENSEN, J.O.T. 1988. Combined effects of gas supersaturation and dissolved oxygen levels on steelhead trout (Salmo gairdneri) eggs, larvae, and fry. Aquacult. 68:131-139.

JENSEN, J.OT., A.N. HALLY and J. SCHNUTE. 1985. Literature data on salmoid response to gas supersaturation and ancillary factors. Can. Data Rep. Fish. Aquat. Sci. 501:iv + 35 pp.

JOHNSON, D.W., and I. KATAVIC. 1984. Mortality, growth and swim bladder stress syndrome of sea bass (Dicentrarchus labrax) larvae under varied environmental conditions. Aquacult. 38:67-78.

JONES, D., and D.H. LEWIS. 1976. Gas bubble disease in fry of channel catfish (ICtalurus punctatus). Prog. Fish-Cult. 38:41.

KOLBEINSHAVN, A., and J.C. WALLACE. 1985 Observations of swim bladder stress syndrome in arctic charr (Salvelinus alpinus), induced by inadequate water depth. Aquacult. 46:259-261.

KRAMER, D.L., and J.P. MEHEGAN. 1981. Aquatic surface respiration, an adaptive response to hypoxia in the guppy, Poecilia reticulata (Pisces, Poeciliidae). Env. Biol. Fishes 6:299-313.

LAYNE, J.N., and D.H. THOMPSON. 1952. Recent collections of the amblyopsid fish Chologaster papillifera in Illinois. Copeia 1952:39-40.

MACHADO, J.P., D.L. GARLING., Jr., N.R. KEVERN., A.L. TRAPP and T.G. BELL. 1987. Histopathology and the pathogenesis of embolism (gas bubble disease) in rainbow trout (Salmo gairdneri). Can. J. Fish. Aquat. Sci. 44:1985-1994.

MARKING, L.L. 1987. Gas supersaturation in fisheries: causes, concerns, and cures. U.S. Fish and Wildl. Serv., Fish and Wildl. Leaflet 9:1-10.

MARSH, M.C., and F.P. GORHAM. 1905. The gas disease in fishes. Rep. U.S. Bur. Fisheries for 1904:343-376.

MATSUE, Y., S. EGUSA and A. SAEKI. 1953. On nitrogen-gas contents dissolved in flowing water of artesian wells and springs (relating to high supersaturation inducing the so-called "gas-disease» upon fishes). Bull. Jap. Soc. Sci. Fish. $19: 439-444$.

MEEKIN, T.K., and R.L. ALLEN. 1974. Nitrogen saturation levels in the midColumbia River, 1965-1971. Washington Dep. Fish. Tech. Rep. 12:32-77.

MISSOURI DEPARTMENT OF CONSERVATION. 1991. Rare and Endangered Species of Missouri Checklist. MDC Natural History Section, Jefferson City, Missouri. $44 \mathrm{pp}$.

MOHR, C.E., and T.L. POULSON. 1966. The Life of the Cave. McGraw-Hill Book Company, New York, New York. 232 pp.

NASH, C.E., C-M. KUO, W.D. MADDEN and C.L. PAULSEN. 1977. Swim bladder inflation and survival of Mugil cephalus to 50 days. Aquacult. 12:89-94.

NELSON, J.S., and M.J. PAETZ. 1974. Evidence for underground movement of fishes in Wood Buffalo National Park, Canada, with notes on recent collections made in the park. Can. Field-Nat. 88:157-162.

PIPER, R.G., I.V. McELWAIN, L.E. ORME, J.P. McCRAREN, L.G. FOWLER and J.R. LEONARD. 1982. Fish Hatchery Management. U.S. Fish and Wildlife Service, Washington, D.C. xxii +517 pp.

POULSON, T.L. 1960. Cave adaptation in amblyopsid fishes. Ph.D. thesis, University of Michigan, Ann Arbor, Michigan. vi + 185 pp.

POULSON, T.L. 1963. Cave adaptation in amblyopsid fishes. Amer. Midl. Nat. 70:257-290.

PUTNAM, F.W. 1875. Exhibition of a number of living specimens of fishes and cray fishes collected in the waters of the Mammoth Cave. Proc. Boston Soc. Nat. Hist. for 1874-1875, 17:222-225.

REGAN, C.T. 1929. Fishes. Pp. 305-329 in Encyclopedia Britannica, 14th edition, volume 9. Encyclopedia Britannica, Inc., New York.

RENFRO, W.C. 1963. Gas-bubble mortality of fishes in Galveston Bay, Texas. Trans. Amer. Fish. Soc. 92:320-322.

RUCKER, R.R. 1975. Gas-bubble disease: mortalities of coho salmon, Oncorhynchus kisutch, in water with constant total gas pressure and different oxygen: nitrogen ratios. Fish. Bull. 73:915-918. 
RUKAVINA, J., and D. VARENIKA. 1956. Air bubble disease of trout at the springs of River Bosna. Acta Ichthyologica Bosniae et Hercegovinae, No. 7, Editium 1, X:5-12. Transl. No. GBL9, Department of Commerce, National Oceanic and Atmospheric Administration, Southeast Fisheries Center, Galveston Laboratory, 4700 Avenue U, Galveston, Texas 77550.9 pp.

SATOMI, Y. 1955. Hydrochemical observation of the ground water for trout culture around Hino-town, Tokyo. Bull. Freshw. Fish. Res. Lab. (Tokyo) 5:31-38.

SCHIEWE, M.H. 1974. Influence of dissolved atmospheric gas on swimming performance of juvenile chinook salmon. Trans. Amer. Fish. Soc. 103:717-721.

SCHUBERT, A.L.S. 1993. Microhabitat selection and feeding in the southern cavefish (Typhlichthys subterraneus). M.S. thesis, University of Missouri-Columbia, Columbia, Missouri. xii $+157 \mathrm{pp}$.

SHIRAHATA, S. 1966. Experiments on nitrogen gas disease with rainbow trout fry. Bull. Freshw. Fish. Res. Lab., Tokyo 15:197-211.

SHRIMPTON, J.M., D.J. RANDALL and L.E. FIDLER. 1990a. Factors affecting swim bladder volume in rainbow trout (Oncorhynchus mykiss) held in gas supersaturated water. Can. J. Zool. 68:962-968.

SHRIMPTON, J.M., D.J. RANDALL and L.E. FIDLER. 1990b. Assessing the effects of positive buoyancy on rainbow trout (Oncorhynchus mykiss) held in gas supersaturated water. Can. J. Zool. 68:969-973.

SMITH, V.J. 1980. Some aspects of the life history of the southern cavefish (Typhlichthys subterraneus Girard) in Missouri. MS. thesis, University of MissouriColumbia, Columbia, Missouri. iii $+123 \mathrm{pp}$.

STROUD, R.K., G.R. BOUCK and A.V. NEBEKER. 1975. Pathology of acute and chronic exposure of salmonid fishes to supersaturated water. Pp. 435-449 in W.A. Adams (ed.). Chemistry and Physics of Aqueous Gas Solutions. The Electrochemical Society, Inc., Princeton, New Jersey. xii +521 pp.

TSVETKOV, V.I., D.S. PAVLOV and V.K. NEZDOLIY. 1972. Changes of hydrostatic pressure lethal to the young of some freshwater fish. J. Ichthyol. 12:307-318.

WEITKAMP, D.E., and M. KATZ. 1980. A review of dissolved gas supersaturation literature. Trans. Amer. Fish. Soc. 109:659-702.

WEISE, J.G. 1957. The spring cave-fish, Chologaster papilleferus, in Illinois. Ecology 38:195-204.

WOODS, L.P., and R.F. INGER. 1957. The cave, spring, and swamp fishes of the family Amblyopsidae of central and eastern United States. Amer. Midl. Nat. 58:232-256. 